\title{
Bahrain Regains Greenery
}

\author{
Sascha Henninger ${ }^{1}$, Hesham Elmarsafawy², Kai Tobias ${ }^{3}$ \\ ${ }^{1}$ Department of Physical Geography, University of Kaiserslautern, Kaiserslautern, Germany \\ ${ }^{2}$ Department of Planning \& Development, Kingdom University, Bahrain, Kingdom of Bahrain \\ ${ }^{3}$ Department of Regional \& Environmental Planning, University of Kaiserslautern, Kaiserslautern, Germany \\ Email: sascha.henninger@ru.uni-kl.de
}

Received 28 July 2015; accepted 28 August 2015; published 31 August 2015

Copyright (C) 2015 by authors and Scientific Research Publishing Inc.

This work is licensed under the Creative Commons Attribution International License (CC BY).

http://creativecommons.org/licenses/by/4.0/

(c) (i)

Open Access

\section{Abstract \\ Bahrain's roofs of private and public buildings despite being flat, are dead, useless, and crammed with lumber and unwanted items. These roofs should be transformed to green and farming spaces.}

\section{Keywords}

\section{Greenery, Local Climate, Green Roofs, Landscaped Roofs}

\section{Introduction}

Due to unemployment, rapid urban growth, marginalization and energy consumption, many urban agglomerations around the world have got major problems today. The future of human life is at risk and this is increasing toward urbanization with the increasing rate of energy consumption and energy resource constraints, in addition to the environmental pollution and waste of the urban residents. The growing consumption of energy and an unbalance between the environment and humans within urban areas, has led the need to adherence a sustainable urban development [1]. In this context, building components can provide a kind of impact to form a self-sufficient building and such a building could lead towards sustainable urban development.

Rooftop greenery could be a good solution for this issue to achieve the goals of sustainable urban development. Using green roof technologies is a good option to improve and sustain the quality of the urban environment or leastwise for the nearby vicinity of the used object. Green roofs can have major environmental impacts on present-day urban areas. The project "Bahrain Regains Greenery" shall introduce roof greenery as a strategy for sustainable urban development particularly in the city of Bahrain/Kingdom of Bahrain.

\section{The Project "Bahrain Regains Greenery"}

An important role to protect and develop the agricultural sector in Bahrain has been undertaken under the patronage of her Royal Highness Princess Sabeeka Bint Ibrahim Al Khalifa. The aim is to achieve the necessary bal- 
ance between agricultural land and urban development in fact of the importance to the people's health and in ensuring domestic food security, without relying on external sources to feed the population. Therefore, the Kingdom University in Bahrain is establishing educational programs, research activities and community services to add new dimensions to the initiatives for environmental and sustainability issues aiming at the prosperity and welfare of the Bahraini community. Hence, the Kingdom University has launched a multi-disciplinary and international research project in collaboration with the University of Kaiserslautern in Germany, called "Bahrain Regains Greenery—Green Roofs in Private \& Public Buildings” (Figure 1).

In this interdisciplinary framework the Kingdom University, the University of Kaiserslautern and the National Initiative for Agriculture Development intend to collaborate in the execution of research and applied projects to contribute to the implementation of the urban agricultural approach, which aims on the most beneficial use of the available spaces and wasted water, in order to attain self-sufficiency in plantings, beside sustain the environment and achieving a healthy as well as a vitality life style as well.

\section{Urban Development and Sustainable Urban Development}

Changes in land use and density levels can be defined as urban development to meet the needs of residents e.g. in the areas of housing, transport and leisure. A development like this could be sustainable, if an urban area is environmentally habitable (e.g. pollution-free surface and groundwater), economically viable (e.g. maintaining basic businesses, providing appropriate and affordable housing for the residents) and socially associated (e.g. fair income, providing adequate shelters, effort to protect the city image).

Since the urban population grow, the dilemma becomes more prominent of how to create and sustain a healthy urban ecosystem. Issues affecting the urban sustainability are the urban heat island effect, heavy precipitation, air pollution, the loss of vegetation and urban green spaces respectively as well as the lack of wildlife habitats are [1]. Specially designed landscapes atop buildings (green roofs) provide solutions to most of these problems and above rise the urban residents quality of life. One of the main challenges of the current urban agglomerations is the development and equitable distribution of urban green spaces in the neighborhoods, especially in city centers, in a manner that is proportional to urban constructions.

So, one of the approaches in architecture and urbanization that arose from the concepts of sustainable development and can be used to increase green spaces, improve the environmental quality and the sustainable urban development is rooftop greenery. The practical use of these roofs can be considered as a possibility for an optimal utilization of the urban landscape.

\section{What Is Roof Greenery?}

Roofs of a building that is partially or completely covered with vegetation and a growing medium, planted over a waterproofing membrane are named green roofing or landscaped roofs. A conventional flat or sloped roof amended with e.g. vapor control, structural support, a waterproofing membrane, roof drainage layers, a root protection layer, thermal insulation and mostly drought-resistant plants is a greened roof.

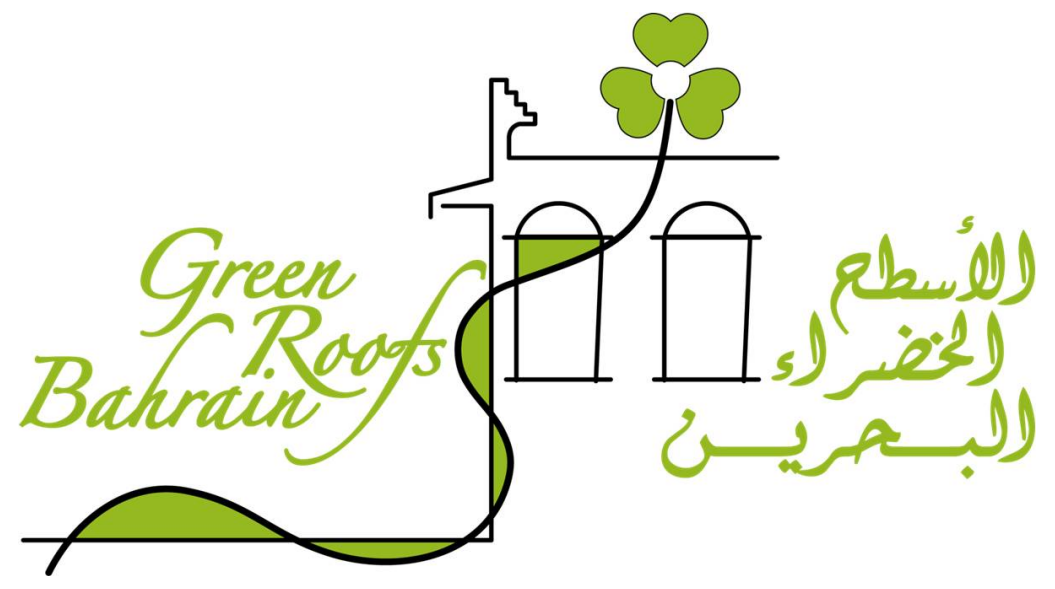

Figure 1. Bahrain regains greenery—green roofs in private \& public buildings. 


\subsection{A Brief History of Rooftop Greenery}

The environmental idea of rooftop greenery started in the late 60's. However, growing plants on a rooftop was not regarded as a really new phenomenon. Isolated samples of landscaped roofs have been used in different countries already in the $18^{\text {th }}$ century. It became more important with the increasing development of urban areas and the loss of open green spaces particularly within these areas. The early twentieth century could be seen as the initial phase in using rooftops or balconies as a functional space. The use of roof space was purely functional and its techniques were different from rooftop greenery technology of nowadays. The quality of the urban environment and environmental challenges of urban agglomerations (e.g. air pollution, the lack of green spaces, the urban heat island effect) started an approach towards a new concept of rooftop greenery as an ecological solution in the 1960's. It began in Northern Europe and soon got its place in most European countries because of their suggested environmental benefits. Especially, Germany, Switzerland, France and Austria initiated activities in this field of research e.g. [2].

\subsection{Green Rooftops}

The differences of greened roofs are the depth of the growing media, the types of plants (dependent on climate), the surrounding infrastructure and intended use and they are generally categorized into two main types: extensive and intensive. Extensive green rooftop greening has a shallow growing media $(<20 \mathrm{~cm})$ and are light-weight structures $\left(<250 \mathrm{~kg} \cdot \mathrm{m}^{-2}\right)$ that covers large expanses of rooftop and requiring minimal maintenance. Intensive landscaped roofs use a deeper growing media $\left(15-200 \mathrm{~cm} ; 200-2000 \mathrm{~kg} \cdot \mathrm{m}^{-2}\right)$ and may also include small trees and shrubs. They are mostly more expensive and their weight has to be considered in the statics e.g. [3]. Due to the usage of the extensive or intensive greening there are a couple of local benefits, which these rooftops could generate, e.g. [4]:

- an increased evaporation rate,

- decreased/deferred surface runoff,

- an improved indoor climate by alteration the thermal capacity,

- an additional thermal insulation by modifying the thermoconductivity,

- a modification of the radiation balance by decreasing the temperature up to $25 \mathrm{~K}$,

- a noise mitigation up to $10 \mathrm{~dB}(\mathrm{~A})$ and

- filtering out air pollutants and airborne particles respectively (15\% - 20\% deposition).

\section{Bahrain Regains Greenery—Green Roofs in Private \& Public Buildings}

On the basis of an international and interdisciplinary workshop at the Kingdom University in Bahrain at the beginning of 2014 this event functioned as the starting point of the innovative project "Bahrain Regains Greenery". Various experts exchanged their knowledge and experience to develop new ideas and possibilities about how to green Bahrain and enrich the quality of life within the kingdom, because of the great potential in respect of the virtuality that there are a lot of square meters of idle private and public building rooftops, which could be transferred to green spaces (Figure 2).

At least two main goals were settled for the project due to the knowledge that the urban vegetation is credited with providing numerous benefits, such as mitigating the urban heat island, improving air quality and
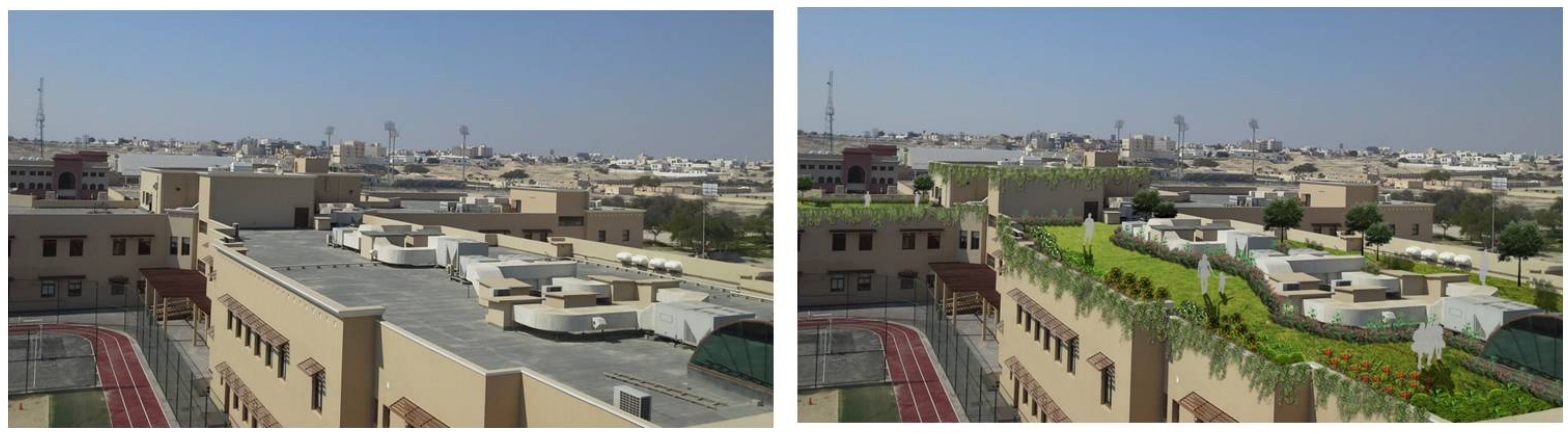

Figure 2. Simulation of the flat rooftops before \& after the “Bahrain Regains Greenery”-project. 
reducing air-conditioning costs in buildings. On the one hand there are the benefits to the local climatic conditions and the irrigation capabilities on the other hand, and of course both could participate from the effects of each other.

\subsection{Positive Local Climatic Effects}

On planted areas within urban settlements could modify the local microclimate as well as the nearby surrounding areas. The availability of water and the resulting increase in evaporation results in lower surface temperatures. A recently irrigated lawn will therefore be cooler than an otherwise similar lawn suffering a shortage of water [5] [6].

Green roofs have a cooling effect as well. They reduce the local air temperature of the buildings as well as for their nearby vicinity [6]. The microclimate of the building is noticeably upgraded. The vegetation can reduce the energy consumption in buildings in hot climates, if air temperature is reduced near the buildings as a result of a planted rooftop-area. Furthermore, the reduction in air temperature resulting from evapotranspiration is accompanied by an increase in the vapour content of the air. Plants may shade building surfaces, reducing the radiant load on the envelope. This may be beneficial in hot conditions. The reduction of surface temperatures resulting from the shade obviously depends upon the extent of the leaf cover. Moreover, the vegetation may reduce wind speed near buildings. This limits unwanted infiltration, but also restricts the potential for ventilation. It reduces convective exchange at buildings surfaces. And additionally, plants in warm climates may reduce temperatures of ground surfaces by evapotranspiration with consequences: cooler surfaces emit less infra-red radiation, thus reducing the radiant load on building surfaces, and release less sensible heat to the adjacent air, so that buildings are exposed to cooler ambient air [5]. Compared with conventional roofs, the surface area of planted roofs is much bigger. The airflow is slowed down and $10 \%$ to $20 \%$ of dust and other air pollutants are filtered by vegetation. Furthermore, deposited nutrients are reused directly for plant growth. Last but not least green roofs protect against storms, ray influences, heat and cold. They increase the thermal insulation and help reduce up to $10 \%$ of energy consumption. Noise insulation of up to $8 \mathrm{~dB}(\mathrm{~A})$ is possible [6].

\subsection{Irrigation Capabilities}

Green roofs can be irrigated by various methods such as using rain water or the building's water feeding system. First, grey water and the water produced from air conditioning units, as a result of de-humidification, can be used for irrigation after passing through a simple treatment process. Secondary, this could lead to a food security by growing certain types of fruits and vegetables on the roofs [7] [8]. Such new green spaces lend itself as areas of renaturation as well as for reproductive cultivation accordingly to the new trend of urban gardening and, of course to improve the urban climate. It offers an opportunity of new forms of urban green spaces, which could e. g. influence the local urban energy budget by a different type of agricultural valorisation. For this reason e. g. sweet potatoes (Ipomoea batatas) could be cultured to proof how urban gardening can affect the ambient temperatures of a rooftop as a kind of cooling equipment reducing the local urban air temperature. Decisive for the choice of sweet potatoes was finding a horticultural product, which can be exposed to environmental stress more easily: in this specific case high ambient temperatures and intensive solar exposure. Corresponding to this, sweet potatoes can grow under stressful conditions, have relatively high abilities of latent heat loss and photosynthetic carbon fixation in comparison to plant species. First results indicated that there are obvious differences in the surface temperature of the exposed rooftop and the vegetation coverage, reaching $-15 \mathrm{~K}$. So, this offered the conclusion that the shadowing of the plants causes a slightly smoother increase of the temperature on the rooftop, what is comparable with the effects of rooftop and façade greening. Furthermore, because of higher ambient temperatures on the rooftop and the increased exposition to the solar radiation, an increased productivity of the sweet potatoes could be mentioned [8]. This kind of rooftop farming could fulfill the daily needs of a family for food, which, on the long term, will contribute to achieving food security for a country with a stretch of land like it is for the Kingdom of Bahrain.

\section{Bahrain Urban Vegetation Database (BUVD)}

The first step to get a first impression of useful urban vegetation for rooftop gardening in the hot and arid climate zone, is to initiate an urban vegetation database with plants that are sensible for the use on a flat rooftop 
with a high sunny exposure. Careful planting of vegetation on buildings have been credited with energy savings of up to $80 \%$ in hot and dry climates. However, in spite of the fact that several studies have been carried out to quantify the effects of vegetation, especially trees, on the energy consumption of buildings, much of the evidence remains anecdotal. Furthermore, since the actual saving possible for any particular building depends upon the properties of the building and its operation, in addition to the effect of vegetation, attempts to derive a broad quantitative estimate of the effect of plants should be treated cautiously [5]. Table 1 exemplarily shows up some datasets of plants and its characteristics, which are part of the urban vegetation database for hot and dry climatic conditions, which at least currently fits more than 200 different types of trees, shrubs, grasses and crops as well.

\section{Concluding Remarks}

Three principals, including economic, environmental and social sustainability, are the fundament of urban sustainable development. So, landscaped roofs within urban areas have advantages in all three pillars:

\subsection{Economic Advantages}

In spite of the initial expense of installation and maintenance, green roofs include fee returns in the duration of use and operation. The most important economic benefits of green roofs are,

- the reduction of heat exchange (thermal insulator) which is a result of an increasing efficiency of air conditioning units,

- the cool down of the rooftops setting as the effect of an increasing efficiency of solar panels,

- the use of an insulating material for the environmental noise or noisy surroundings respectively [9].

\subsection{Environmental Advantages}

Air pollutants can be reduced by absorbing carbon dioxide and producing oxygen as well as by depositing e.g. particulate matters by building green rooftops on a massive scale in the urban areas. The main environmental benefits of green roofs are:

- an improvement of the water management for the surface runoff,

- a diminution on the local heat island effect,

- less air of pollutants, and

- the possibility to create new animal habitats within the new urban green areas e.g. [10] [11].

\subsection{Social Advantages}

Human societies are the main axis of a sustainable development. The goals of a sustainable urban development cannot be undertaken without social development. In general, sustainable development has to achieve a vibrant

Table 1. Examples of different datasets of the urban vegetation database for different types of vegetation suitable for rooftop-greenery.

\begin{tabular}{|c|c|c|}
\hline Scientific name & Watering conditions & Light- and thermal conditions \\
\hline Acacia berlandieri & $\begin{array}{l}\text { - Resident to drought } \\
\text { - Low water use } \\
\text { - Soil moisture: dry }\end{array}$ & - Prefers a sunny to half-shady situation on dry soil \\
\hline Acacia gerrardii & $\begin{array}{l}\text { - Resident to drought } \\
\text { - No excessive irrigation; only one bucket } \\
\text { of water every } 4 \text { - } 5 \text { weeks }\end{array}$ & $\begin{array}{l}\text { - Exposure: full sun } \\
\text { - Resident to frost }\end{array}$ \\
\hline Draceana bicolour & - Requires little watering & $\begin{array}{l}\text { - Exposure: full sun or semi shade } \\
\text { - Withstands high temperature }\end{array}$ \\
\hline Eucalyptus subcinerea & - Resident to drought & $\begin{array}{l}\text { - Prefers a sunny situation on dry to moderately moist soil } \\
\text { - Tolerates temperatures down to }-7^{\circ} \mathrm{C} \\
\text { - Needs a frost-free period of at least } 26 \text { weeks }\end{array}$ \\
\hline Pistacia vera & - Resident to drought & $\begin{array}{l}\text { - Prefers a sunny situation on dry to moderately moist soil } \\
\text { - Tolerates temperatures down to }-7^{\circ} \mathrm{C}\end{array}$ \\
\hline
\end{tabular}


and sustainable community, but without environmental protection this is impossible. Since the new urban landscape is visible to pedestrians and residents, beautifying the urban environment is one of the most important social benefits of roof greenery. The use of green roofs as communal spaces could increase the social interaction among residents in a pleasant and desirable environment [12].

Although studying most of the above mentioned effects has been the subjects of agriculture and forest meteorology for many years, these also have a great importance within urban areas, because whereas planted areas may comprise only a small percentage of the overall urban surface, they are very different in their characterization and impact. Roof gardens are perhaps the most obvious example of the use of plants to control building energy performance. Likewise it is credited with improving the urban microclimate as well. The shading and the evapotranspiration of the plants contribute to lower surface temperatures and thus to lower heat gains through the roof, which are also moderated by the large heat capacity of the soil. Therefore, the interdisciplinary project “Bahrain Regains Greenery-Green Roofs in Private \& Public Buildings” offered a great potential of altering the local urban climate, by reducing the energy demand of the according vegetated buildings and improving the local supply with food.

\section{References}

[1] Henninger, S. (2011) Stadtökologie. Schöningh Verlag, Paderborn. (In German)

[2] Appl, R. (2009) Past-Present-Future: Green Roof Techniques in Changing Times. Green Roofs-Bringing Nature Back to Town. International Roof Congress, Berlin, 25-27 May 2009, 7-14.

[3] Walker, R. (2009) Technical Solutions for Intensive Greenery_Life on Roofs. Green Roofs_Bringing Nature Back to Town. International Roof Congress, Berlin, 25-27 May 2009, 33-40.

[4] Henninger, S. (2010) Energieeffizientes Bauen. Koblenzer Geographisches Kolloquium, Koblenz, December 2010, 5365. (In German)

[5] Errel, E., Pearlmutter, D. and Williamson, T. (2011) Urban Microclimate-Designing the Spaces between Buildings. Earthscann Books, London.

[6] Henninger, S. (2011) Urban Green Areas: Lots of Benefits, but Some Drawbacks. REAL CORP 2011: Change for Stability: Lifecycles of Cities and Regions, Essen, 18-20 May 2011, 1069-1077.

[7] Yoshiaki, K., Masashi, Y., Hiroaki, H. and Shibuya, T. (2009) Rooftop Farming with Sweet Potato for Reducing Urban Heat Island Effects and Producing Food and Fuel Materials. The 7th International Conference on Urban Climate, Yokohama, 29 June-3 July 2009.

[8] Henninger, S. (2012) Urban Gardening and Urban Climate. 32nd International Geographical Congress, Cologne, 26-30 August 2012, 684.

[9] Ansel, W. (2009) Green Roofs Incentives in Germany-Proven Procedures and Current Trends. Green Roofs—Bringing Nature Back to Town. International Roof Congress, Berlin, 25-27 May 2009, 123-126.

[10] Roth-Kleyer, S. (2009) Green Roofs as a Module of Urban Water Management. Green Roofs_Bringing Nature Back to Town. International Roof Congress, Berlin, 25-27 May 2009, 63-72.

[11] Köhler, M. (2009) Energetic Aspects of Green Roofs. Green Roofs_Bringing Nature Back to Town. International Roof Congress, Berlin, 25-27 May 2009, 63-72.

[12] Martinez, A. (2009) Roof as Living Space-Examples from Spain. Green Roofs_Bringing Nature Back to Town. International Roof Congress, Berlin, 25-27 May 2009, 41-44. 